\title{
Growth analysis of green-leaf lettuce under different sources and doses of organic and mineral fertilization
}

\section{Análisis de crecimiento de lechuga crespa bajo diferentes fuentes y dosis de fertilización orgánica y mineral}
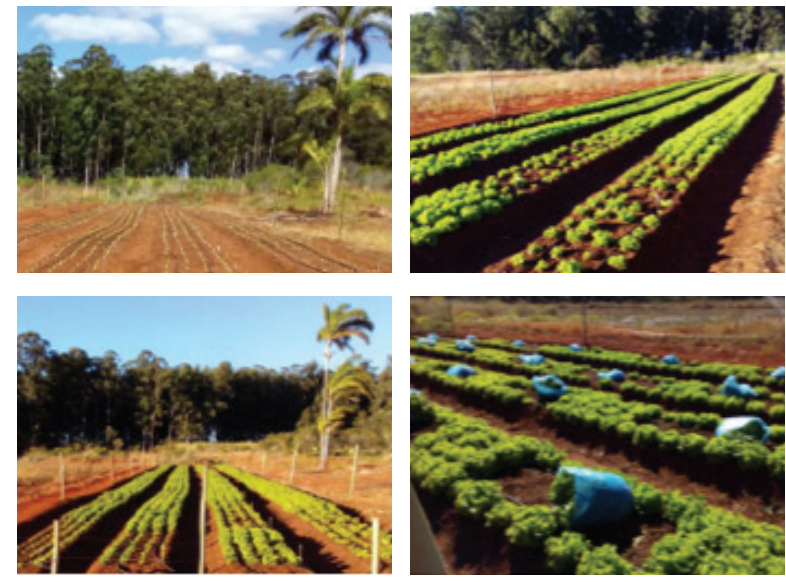

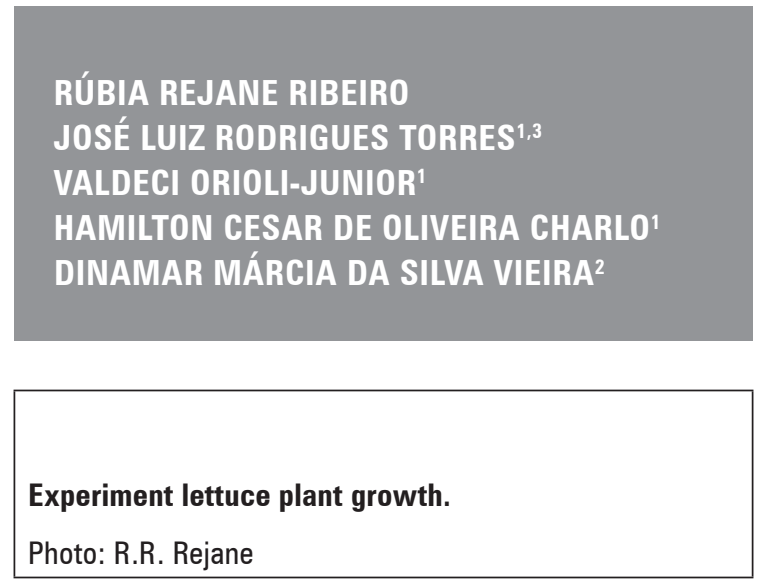

\section{ABSTRACT}

The objective of this study was to evaluate the influence of different sources and doses of organic and mineral fertilization on the production of green-leaf lettuce. The experiment design used randomized blocks in a factorial scheme $(6 \times 3)$, with six doses of fertilizers $(1=0 ; 2=25 ; 3=50 ; 4=100 ; 5=150$, and $6=200 \%$ of the recommended fertilization for green-leaf lettuce crop) and three sources of fertilizers [cattle manure (CaM) and chicken manure (ChM), decomposed, on a wet basis and applied $100 \%$ at planting at the doses: CaM - 0, 12.5, 25, 50, 75, $100 \mathrm{Mg} \mathrm{ha}^{-1}$; ChM - 0, 5, 10, 20, 30, $40 \mathrm{Mg} \mathrm{ha}^{-1}$; mineral fertilization (MF) varying the $\mathrm{N}$ levels: $0,37.5,75,150,225,300 \mathrm{~kg} \mathrm{ha}^{-1}$ plus $400 \mathrm{~kg} \mathrm{ha}^{-1}$ of $\mathrm{P}_{2} \mathrm{O}_{5}$ and $60 \mathrm{~kg} \mathrm{ha}^{-1}$ of $\mathrm{K}_{2} \mathrm{O}$ ]. The fertilization with $\mathrm{CaM}$ and $\mathrm{ChM}$ was more efficient than the MF at increasing the production of green-leaf lettuce, mainly because of the higher residual effects of $\mathrm{P}$ in the Oxisol. The ChM provided a higher soil $\mathrm{pH}, \mathrm{P}$ and $\mathrm{K}$, while the CaM provided a higher soil $\mathrm{Mg}$, organic carbon and organic matter. The dose with $144 \%$ of organic fertilization exclusively on a wet basis corresponding to $72 \mathrm{Mg} \mathrm{ha}^{-1}$ of CaM and $29 \mathrm{Mg} \mathrm{ha}^{-1}$ of ChM resulted in the highest green-leaf lettuce yield.

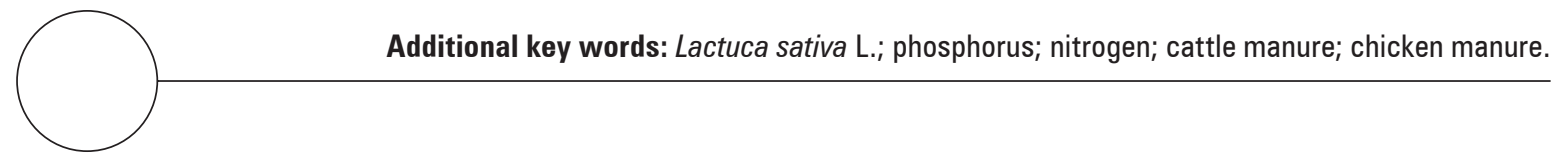

\footnotetext{
1 Federal Institute of Education, Science and Technology of Triangulo Mineiro, Uberaba (Brazil). ORCID Ribeiro, R.R.: 0000-0003-1637-9900; ORCID Torres, J.L.R.: 0000-0003-4211-4340; ORCID Oliari-Junior, V.: 0000-0001-6202-7100; ORCID Charlo, H.C.O.: 0000-0003-0663-2167

2 Federal University of Uberlândia, Institute of Agricultural Sciences, Uberlandia (Brazil). ORCID Vieira, D.M.S.: 00000003-4740-0549

3 Corresponding author. jlrtorres@iftm.edu.br
} 


\section{RESUMEN}

El objetivo de este estudio fue evaluar la influencia de diferentes fuentes y dosis de fertilización orgánica y mineral en la producción de lechuga crespa. Se utilizó un diseño de bloques completos al azar, en un esquema factorial $(6 \times$ $3)$, donde se evaluaron seis dosis de fertilizante $(1=0,2=25 ; 3=50 ; 4=100 ; 5=150$ y $6=200 \%)$ de la fertilización recomendada para la lechuga, tres fuentes de abono fertilizante (estiércol bonino (EB) y aves de corral (CP)), descompuesto, aplicado húmedo $100 \%$ en la siembra: 1 = EB - 0; 12,5;25; 50; 75 y $100 \mathrm{Mg} \mathrm{ha}^{-1} ; 2$ = CP 0; 5; 10;20; 30 y $40 \mathrm{Mg} \mathrm{ha}^{-1} ; 3=$ Fertilización mineral varió solo las cantidades de $\mathrm{N} ; 3=0 ; 37,5 ; 75 ; 150 ; 225$ y $300 \mathrm{~kg} \mathrm{ha}^{-1}$, junto a $400 \mathrm{~kg} \mathrm{ha}^{-1}$ de $\mathrm{P}_{2} \mathrm{O}_{5}$ y $60 \mathrm{~kg} \mathrm{ha}^{-1}$ de $\mathrm{K}_{2} \mathrm{O}$ que se mantuvo en las parcelas con fertilización mineral. La fertilización con EB y CP demostró ser más eficiente que la fertilización mineral en la producción de lechuga crespa, principalmente debido a los mayores efectos residuales del $\mathrm{P}$ en el suelo. El estiércol CP proporcionó valores más altos de $\mathrm{pH}, \mathrm{P}$ y $\mathrm{K}$, mientras que el EB de $\mathrm{Mg}$, materia orgánica y carbono orgánico en el suelo. La dosis del $144 \%$ de fertilizantes exclusivamente orgánicos en base húmeda correspondiente a estiércol de $72 \mathrm{Mg} \mathrm{ha}^{-1} \mathrm{~EB}$ y $29 \mathrm{Mg} \mathrm{ha}^{-1} \mathrm{CP}$, dieron los mejores rendimientos para la lechuga crespa en un Latosol.

Palabras clave adicionales: Lactuca sativa L.; fósforo; nitrógeno; estiércol de ganado; estiércol de aves.

Received for publication: 20-10-2018 Accepted for publication: 31-07-2019

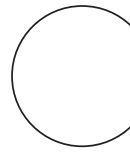

Lettuce (Lactuca sativa L.) is the most cultivated leafy vegetable in Brazil. The States of São Paulo and Minas Gerais are the major producers, where green-leaf lettuce enjoys consumer preference, reaching $70 \%$ of the market, followed by American lettuce (15\%), flat lettuce $(10 \%)$ and $5 \%$ for other commercial types (Sala and Costa, 2012). In recent years, the consumption of processed lettuce has grown significantly, mainly serving fast-food restaurants, industries and hospitals (Mota et al., 2012).

As a short cycle plant, lettuce uses high quantities of mineral fertilizers to meet plant development demands (Queiroz et al., 2017), mainly for nitrogen (N). This nutrient is the most required macronutrient in horticultural crops; however, this nutrient presents great losses through leaching, volatilization, and immobilization, requiring special care in its management (Carvalho and Zabot, 2012).

The frequent increase in the cost of mineral fertilizers and increasing environmental pollution as a result of inappropriate agricultural activities highlight the use of organic fertilizers as an attractive option. Organic fertilizers are attractive for all farm sizes because of nutrient cycling and organic matter addition, which may modify a soil's physical, chemical and biological attributes, thus improving soil fertility (Pereira et al., 2013). These potential effects of organic fertilizers have generated new demands on researchers for assessing the technical and economic feasibility of such fertilizers (Melo et al., 2008).

Agricultural activities produce plant and animal (manure) waste in large quantities, which has been used in agriculture for thousands of years but requires more efficient management in the fertilization of agricultural crops, mainly in vegetable crops with a short cycle (Figueiredo et al., 2012; Vergel et al., 2016). Knowledge on the dynamics of nutrient mineralization must be fully understood to improve nutrient availability in the soil of short-cycle crops, avoiding immobilization or rapid mineralization of nutrients during periods of high or low demand (Peixoto Filho et al., 2013; Vaz et al., 2019).

Bovine (cattle) manure (CaM) is widely used as an organic fertilizer for the production of vegetables. When this fertilizer is incorporated, it improves soil aeration and water absorption, as well as the chemical, physical and biological properties of the soil, generating a more balanced nutrient availability for plants (Cunha et al., 2012). Abreu et al. (2010) emphasized that CaM has a water $\mathrm{pH}$ of $6.7,26.9 \mathrm{~g} \mathrm{~kg}^{-1}$ of organic matter, $\mathrm{N}, \mathrm{P}, \mathrm{K}, \mathrm{Ca}, \mathrm{Mg}$ and $\mathrm{S}$ at 11.4, 16.1, 8.3, 62, 13 and $6.7 \mathrm{~g} \mathrm{~kg}^{-1}$; and $\mathrm{B}, \mathrm{Cu}, \mathrm{Fe}, \mathrm{Mn}$ and $\mathrm{Zn}$ at 7.24, 67.8, 147, 146 and $119 \mathrm{mg} \mathrm{kg}^{-1}$ (dry basis), respectively. However, this composition depends on 
animal feed because, when done exclusively in pastures, these values are different than where there is supplementation with concentrates (Peixoto Filho et al., 2013). In contrast, chicken manure (ChM) from intensive farming (poultry) is richer in nutrients, water $\mathrm{pH}$ of $8.4,31.1 \mathrm{~g} \mathrm{~kg}^{-1}$ of organic matter $(\mathrm{OM}), \mathrm{N}$, $\mathrm{P}, \mathrm{K}, \mathrm{Ca}, \mathrm{Mg}$ and $\mathrm{S}$ at 32.2; 22.6, 30, 171, 8.9 and $6.9 \mathrm{~g}$ $\mathrm{kg}^{-1}$; and $\mathrm{B}, \mathrm{Cu}, \mathrm{Fe}, \mathrm{Mn}$ and $\mathrm{Zn}$ at 36.5, 69.6, 272, 583 and $631 \mathrm{mg} \mathrm{kg}^{-1}$ of in dry basis, respectively (Abreu et al., 2010).

In addition, manure fertilizers contain high levels of cellulose, which make residue decomposition and nutrient release slowly, generating positive consequences in vegetable crops (Souza, 2007). The contents of $\mathrm{N}, \mathrm{P}$ and $\mathrm{K}$ in ChM are at higher concentrations than in other species of domestic animals since it contains 5 to $15 \%$ water, while other manures have 65 to $85 \%$ (Tedesco et al., 2008). Using ChM as a form of fertilizer, Abreu et al. (2010) and Peixoto Filho et al. (2013) demonstrated that lettuce presented better root development and improved production of dry mass and yield when compared to other forms of organic fertilization.

The majority of studies assess the productivity of lettuce after the application of different sources of organic fertilization, but results vary according to the region, soil type and form of irrigation; however, only a few studies have assessed the residual effect of organic fertilization on the production of lettuce in the Cerrado biome. The objective of this study was to evaluate the influence of different sources and doses of organic and mineral fertilization on the production of green-leaf lettuce.

\section{MATERIAL AND METHODS}

The study was conducted in the experimental area of the horticulture sector of the Federal Institute of Triângulo Mineiro, Campus Uberaba, at the coordinates $19^{\circ} 45^{\prime} 27^{\prime \prime}$ S; $47^{\circ} 55^{\prime} 36^{\prime \prime} \mathrm{W}$, at an altitude of 764 $\mathrm{m}$ a.s.l. The experimental area was previously prepared with two harrowings, followed by a soybean cultivation cycle and two years without crop activities before the experiment was installed in the winter of 2017.

The climate of the region is characterized as tropical rainy, with a cold dry winter and hot humid summer - Aw climate type, according to Beck et al. (2018). The average annual precipitation and temperature are $1,600 \mathrm{~mm}$ and $22.6^{\circ} \mathrm{C}$, respectively (Inmet, 2018); however, during the evaluation period, rainfall of 20 $\mathrm{mm}$ (June/2017) was recorded; the total accumulated in the year was $1,995.3 \mathrm{~mm}$, above the normal for the region (Fig. 1).

The soil of the experimental area was classified as a dystrophic red latosol (Santos et al., 2018), medium texture, presenting the following values in the $0-0.2$ $\mathrm{m}$ layer four months prior to the liming: 210, 680 and $110 \mathrm{~g} \mathrm{~kg}^{-1}$ of clay, sand and silt, respectively, $\mathrm{pH}$ $\left(\mathrm{CaCl}_{2}\right) 6.5 ; 20.9 \mathrm{mg} \mathrm{dm}^{-3}$ of P (Mehlich-1); $161 \mathrm{mg}$ $\mathrm{dm}^{-3}$ of $\mathrm{K}^{+} ; 2.9 \mathrm{cmol}_{\mathrm{c}} \mathrm{dm}^{-3}$ of $\mathrm{Ca}^{2+} ; 1.5 \mathrm{cmol}_{c} \mathrm{dm}^{-3}$ of $\mathrm{Mg}^{2+} ; 2 \mathrm{cmol}_{\mathrm{c}} \mathrm{dm}^{-3}$ of $\mathrm{H}+\mathrm{Al}$ and $18 \mathrm{~g} \mathrm{~kg}^{-1}$ of organic matter and base saturation (V) of $71 \%$.

The sowing of the green-leaf lettuce (Vanda cultivar, Sakata $\left.{ }^{\circledR}\right)$ occurred in plastic trays (200 cells), grown under greenhouse conditions prior to field transplant.

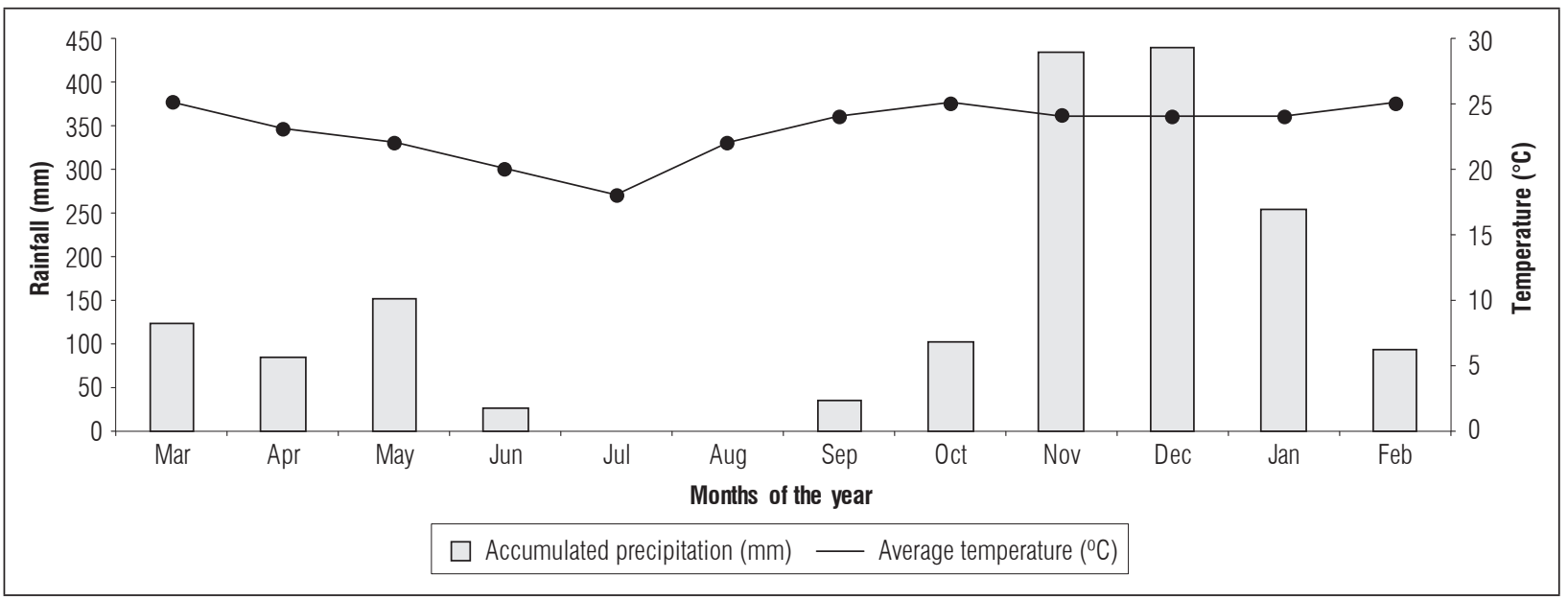

Figure 1. Climate variables obtained from the Meteorological Database for Teaching and Research (Inmet, 2018). 
The seedlings were transplanted when they presented 4 to 6 final leaves that were completely expanded (7 to $10 \mathrm{~cm}$ height), approximately $25-30$ days after sowing (DAS), and spaced $0.25 \mathrm{~m}$ between plants and between rows, in 4 planting rows, with 10 plants per row (40 plants per plot) in plots $1 \mathrm{~m}$ apart. The experiment plots were mechanically built and were $0.3 \mathrm{~m}$ tall, with $2.5 \times 1 \mathrm{~m}\left(2.5 \mathrm{~m}^{2}\right)$. In each plot, only 12 plants from the two central rows were evaluated.

The experiment design used the randomized block design in a $6 \times 3$ factorial scheme, with six doses of fertilizers $(0,25,50,100,150$ and $200 \%$ of the recommended fertilization for lettuce crop) and three fertilizers sources [cattle manure (CaM) and chiken (hens) manure (ChM), decomposed, on a wet basis and applied $100 \%$ at planting at the doses: $\mathrm{CaM}-0$, 12.5, 25, 50, 75, $100 \mathrm{Mg} \mathrm{ha}^{-1}$; ChM - 0, 5, 10, 20, 30, $40 \mathrm{Mg} \mathrm{ha}^{-1}$; mineral fertilization (MF) varying the $\mathrm{N}$ levels: $0,37.5,75,150,225,300 \mathrm{~kg} \mathrm{ha}^{-1}$ of $\mathrm{N}$ as urea, plus $400 \mathrm{~kg} \mathrm{ha}^{-1}$ of $\mathrm{P}_{2} \mathrm{O}_{5}$ (superphosphate, $20 \% \mathrm{P}_{2} \mathrm{O}_{5}$ ) and $60 \mathrm{~kg} \mathrm{ha}^{-1}$ of $\mathrm{K}_{2} \mathrm{O}\left(\mathrm{KCl}, 60 \% \mathrm{~K}_{2} \mathrm{O}\right)$, as recommended in Ribeiro et al. (1999) - urea and $\mathrm{KCl}$ were fractioned: $20 \%$ at planting, 20, 20 and $40 \%$ in successive side-dressing fertilizations; all treatments had 4 replications $(n=72)$. The organic fertilizers and minerals were distributed and incorporated in the plots 5 and $3 \mathrm{~d}$ before seedling transplant, respectively.

The lettuce plants were irrigated daily (drippers), with a flow rate of $1.8 \mathrm{~L} \mathrm{~h}^{-1}$ spaced every $0.5 \mathrm{~m}$, for approximately $40 \mathrm{~min}$, maintaining the soil close to field capacity. Infestant plants (weeds) were manually controlled.

The harvest occurred 67 DAS and 42 days after transplant (DAT), when the plants presented commercial standards without evidence of flowering and with the maximum vegetative development. The plants were cut just below the basal leaves, close to the soil level, and brought to the laboratory to conduct the evaluations.

After the lettuce harvesting, the number of leaves $(\mathrm{NL})$ was quantified, the plant height $(\mathrm{PH})$ was measured with a graded ruler and the stem diameter (SD) were evaluated with caliper; the shoot fresh mass (SFM), shoot dry mass (SDM) and yield (P) were recorded using a digital scale with a maximum capacity of $20 \mathrm{~kg}$. The harvested plants were dried at $65^{\circ} \mathrm{C}$ with a forced air circulation oven for $72 \mathrm{~h}$ to determine the dry mass (SDM).
Four days after harvest, soil samples were collected in each plot in the $0-0.2 \mathrm{~m}$ soil layer for chemical analysis and determination of the residual effect of the fertilizers. The soil water $\mathrm{pH}$, phosphorus $(\mathrm{P})$ by Mehlich-1, potassium $\left(\mathrm{K}^{+}\right)$, calcium $\left(\mathrm{Ca}^{2+}\right)$, magnesium $\left(\mathrm{Mg}^{2+}\right)$, potential acidity $(\mathrm{H}+\mathrm{Al})$, soil organic matter $(\mathrm{SOM})$, sum of bases $(\mathrm{Ca}+\mathrm{Mg}+\mathrm{K}+\mathrm{Na})(\mathrm{SB})$, effective cation exchange capacity $(\mathrm{CEC})(\mathrm{t}=\mathrm{SB}+$ $\left.\mathrm{Al}^{3+}\right), \mathrm{CEC}$ at $\mathrm{pH} 7(\mathrm{~T}=\mathrm{SB}+(\mathrm{H}+\mathrm{Al}))$, and base saturation $(\mathrm{V}=100 \mathrm{SB} / \mathrm{T})$ were recorded.

The results were submitted to analysis of variance using the $\mathrm{F}$ test for significance. When the results presented significant differences $(P<0.05)$, the data were submitted to analysis of regression for the quantitative factors (doses) and Tukey's test to the averages of qualitative factors (sources), both at $5 \%$ probability, using the AGROESTAT statistical software.

\section{RESULTS AND DISCUSSION}

The lettuce morphological parameters when using the CaM and ChM fertilizers were significantly higher $(P<0.05)$ than when mineral fertilizer was applied (urea). For the doses, 150 and $0 \%$ were significantly higher and lower than the other doses for all parameters, respectively, but there was no interaction between the sources and doses (Tab. 1).

The use of CaM and ChM improved the soil chemical attributes after soil incorporation and increased all agronomic characteristics of the green-leaf lettuce. These results were due to the low natural fertility of Oxisols in the Cerrado biome. These soils generally present an accelerated rate of plant residue decomposition, low levels of organic matter, $\mathrm{Ca}, \mathrm{Mg}, \mathrm{P}$ and, consequently, a low cationic exchange capacity; thus, the use of organic fertilizers can improve the attributes of such soils.

Cunha et al. (2012) and Oliveira et al. (2014) showed that the application of organic compounds improves soil aeration and water absorption, as well as the chemical, physical and biological soil attributes, generating a balance in the availability of nutrients to plants as a function of useful microorganisms, macro and micronutrients that are available, natural antibiotics and growth substances, such as the humic fractions of organic matter.

The organic fertilization not only boosted productivity but also produced plants with a better nutritional 
Table 1. Agronomic evaluation of green-leaf lettuce under different fertilizers and doses.

\begin{tabular}{|c|c|c|c|c|c|c|}
\hline \multirow{3}{*}{ Fertilizer } & \multirow{2}{*}{ NL } & $\mathrm{PH}$ & SD & SFM & SDM & Yield \\
\hline & & \multicolumn{2}{|c|}{$\mathrm{cm}$} & \multicolumn{2}{|c|}{$\mathrm{g} /$ plant } & $\mathrm{Mg} \mathrm{ha}^{-1}$ \\
\hline & \multicolumn{6}{|c|}{ Fertilizers (F) } \\
\hline Urea & $16.4 b$ & $13.9 \mathrm{~b}$ & $1.1 \mathrm{~b}$ & $78.5 b$ & $3.4 b$ & $12.6 \mathrm{~b}$ \\
\hline ChM & $22.0 \mathrm{a}$ & $16.8 \mathrm{a}$ & $1.5 \mathrm{a}$ & $159.8 \mathrm{a}$ & $9.4 \mathrm{a}$ & $25.6 \mathrm{a}$ \\
\hline CaM & $23.2 \mathrm{a}$ & $17.5 \mathrm{a}$ & $1.5 \mathrm{a}$ & $172.2 \mathrm{a}$ & $9.8 \mathrm{a}$ & $27.5 \mathrm{a}$ \\
\hline \multirow[t]{2}{*}{ F-test } & $65.87^{* *}$ & $18.45^{* *}$ & $28.69 * *$ & $39.09^{* *}$ & $34.89 * *$ & $39.09 * *$ \\
\hline & \multicolumn{6}{|c|}{ Doses (D) } \\
\hline 0 & $16.2 \mathrm{c}$ & $12.8 \mathrm{c}$ & $1.0 \mathrm{c}$ & $62.7 \mathrm{~d}$ & $3.5 b$ & $10.0 \mathrm{~d}$ \\
\hline 25 & 19.8 b & $15.1 \mathrm{bc}$ & $1.3 \mathrm{~b}$ & $113.5 \mathrm{c}$ & $6.8 \mathrm{ab}$ & $18.1 \mathrm{c}$ \\
\hline 50 & $21.0 \mathrm{ab}$ & $16.1 \mathrm{ab}$ & $1.4 \mathrm{~b}$ & 134.2 bc & $7.8 \mathrm{a}$ & $21.5 b c$ \\
\hline 100 & $22.0 \mathrm{ab}$ & $17.1 \mathrm{ab}$ & $1.5 \mathrm{a}$ & $164.7 b$ & $8.7 \mathrm{a}$ & $26.3 b$ \\
\hline 150 & $23.0 \mathrm{a}$ & $18.5 \mathrm{a}$ & $1.5 \mathrm{a}$ & 185.7 a & $9.3 \mathrm{a}$ & $29.7 \mathrm{a}$ \\
\hline 200 & $21.6 \mathrm{ab}$ & $17.0 \mathrm{ab}$ & $1.4 \mathrm{~b}$ & $160.3 b$ & $9.3 \mathrm{a}$ & $25.6 b$ \\
\hline \multirow[t]{2}{*}{ F-test } & $13.53^{* *}$ & $9.71^{* *}$ & $10.93^{* *}$ & $14.75^{* *}$ & $6.57^{* *}$ & $14.75^{*}$ \\
\hline & \multicolumn{6}{|c|}{ Interaction $\mathrm{F} \times \mathrm{D}$} \\
\hline F-test & $1.16^{\mathrm{ns}}$ & $0.69^{\text {ns }}$ & $0.86^{\mathrm{ns}}$ & $0.96^{\mathrm{ns}}$ & $0.92^{\mathrm{ns}}$ & $0.96^{\mathrm{ns}}$ \\
\hline CV (\%) & 10.69 & 13.68 & 14.24 & 29.14 & 39.24 & 29.13 \\
\hline
\end{tabular}

${ }^{n s}=$ non significant; ${ }^{* *}=$ significant at $5 \%$, by the Tukey test $(P<0.05)$.

$\mathrm{ChM}=$ chicken manure; $\mathrm{CaM}=$ cattle manure; $\mathrm{NL}=$ number of leaves; $\mathrm{PH}=$ plant height; $\mathrm{SD}=$ stem diameter; $\mathrm{SFM}=$ shoot fresh mass; $\mathrm{SDM}=$ shoot dry mass.

quality (arising from the improvement of soil quality) than the plants grown exclusively with mineral fertilizers (Silva et al., 2011). Oliveira et al. (2014) emphasized that leafy vegetables respond well to organic fertilization and that the constant use of mineral fertilizers causes reductions in a soil's biological activity, which can affect the productive performance of crop cultures. Vaz et al. (2019) emphasized in their study that the commercial productivity of $14.5 \mathrm{Mg}$ ha $^{-1}$ was observed at $157.4 \mathrm{~kg}$ of formulated $05-25-15$ (NPK) and that doses above $200 \mathrm{~kg} \mathrm{ha}^{-1}$ reduced the number of total leaves and productivity.

The polynomial regression analysis demonstrated that the best fit to the averages of the analyzed variables was the quadratic model for NL, PH, SD, SFM, SDM and yield; the maximum values were 23.9, 17.4 and $1.6 \mathrm{~cm}, 182.4$ and $11 \mathrm{~g} /$ plant and $29.5 \mathrm{Mg} \mathrm{ha}^{-1}$, which corresponded to the doses 229.5, 181.5, 195, $213,274.5$ and $216 \mathrm{~kg} \mathrm{ha}^{-1}$ of $\mathrm{N}$, which were equivalent to $153,121,130,142,183$ and $144 \%$ of the recommended dose, respectively (Fig. 2).

According to Filgueira (2013), increases in the NL and $\mathrm{PH}$ favor vegetative development and expand the photosynthetically active area of plants, raising the productive potential. This response was seen in the present study since, in the plots fertilized with CaM, the NL and HP increased by 43.7 and $25.9 \%$, which caused an increase of $36.6 \%$ in the SD, $119.4 \%$ in the SFM, $188.23 \%$ in SDM and $118.25 \%$ in the lettuce productivity. In the plots fertilized with ChM, the values did not differ from the plots with CaM $(P>0.05)$; the $\mathrm{NL}$ and $\mathrm{PH}$ increased by 37.5 and $20.9 \%$, which caused an increase of $36.6 \%$ in $\mathrm{SD}$, $103.6 \%$ in SFM, $176.5 \%$ in SDM and $103.2 \%$ in the productivity when compared to the plots with mineral fertilization.

The study of the production of lettuce (Vanda cultivar) grown under protected environments and in an open field, with organic and mineral fertilization, using doses of 0,1 and 2 times the recommendation for organic compost ( $3.6 \mathrm{~kg} \mathrm{~m}^{-2}$ of NPK), mineral fertilizer $\left[0.02 \mathrm{~kg} \mathrm{~m}^{-2}\right.$ of $\mathrm{N}$, via urea, $0.08 \mathrm{~kg} \mathrm{~m}^{-2}$ of $\mathrm{P}$ (simple superphosphate), and $\left.0.008 \mathrm{~kg} \mathrm{~m}^{-2} \mathrm{~K}(\mathrm{KCl})\right]$, indicated that the open environment had the highest averages with the highest dose of organic fertilization for $\mathrm{PH}$ $(15.6 \mathrm{~cm})$, the recommended dose of mineral fertilization for NL (8.6) and SD $(1.13 \mathrm{~cm})$ and a greater 


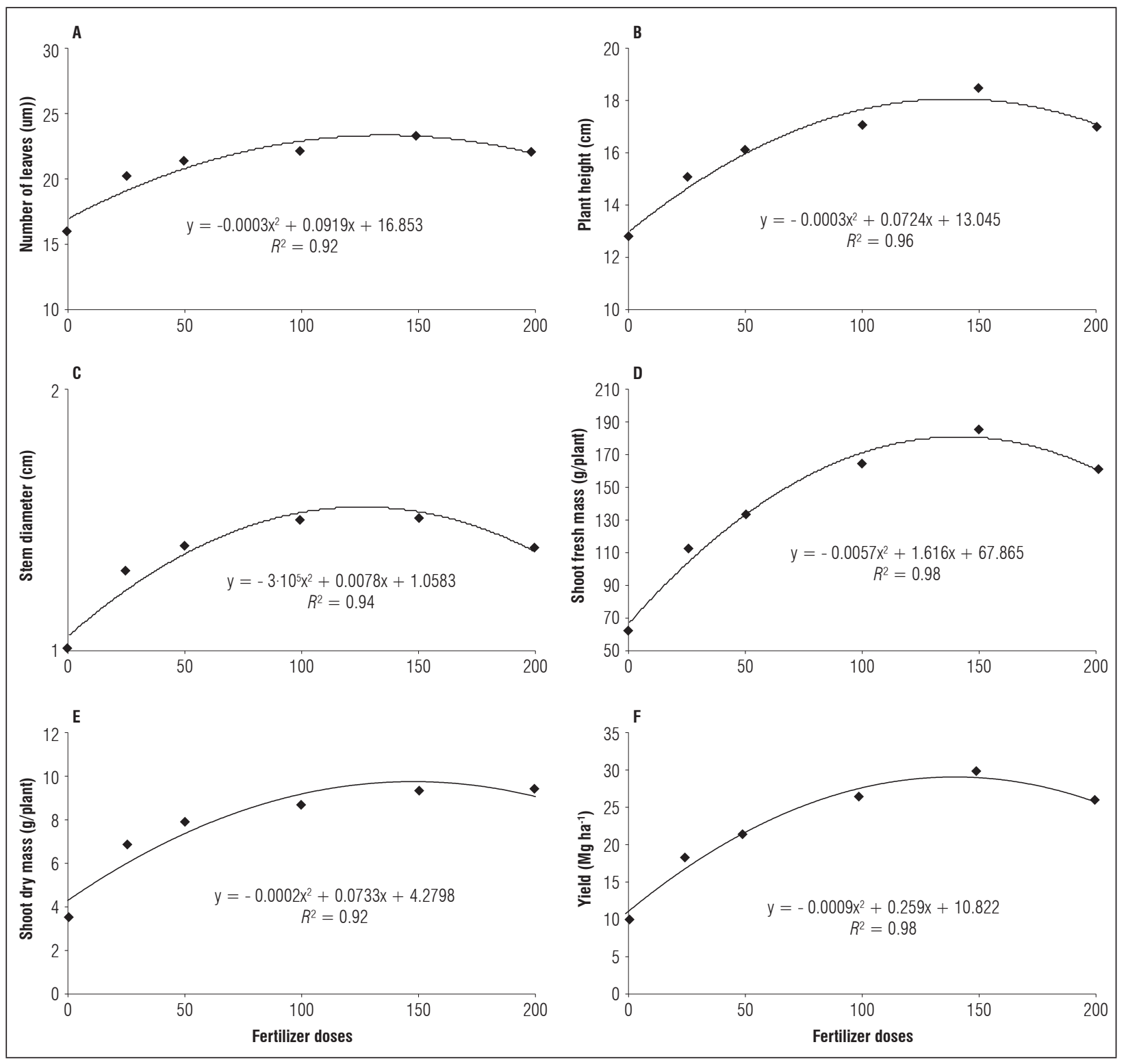

Figure 2. Effect of doses in the lettuce for number of leaves (A), plant height (B), stem diameter (C), shoot fresh mass (D), shoot dry mass $(E)$, and yield $(F)$, corresponding to the doses of $229.5(153 \%), 181.5(121 \%), 195.0(130 \%), 213.0(142 \%)$, $274.5(183 \%)$ and $216.0(144 \%) \mathrm{kg} \mathrm{ha}^{-1}$ of $\mathrm{N}$.

dose of mineral fertilization for SFM (96.8 g/plant) and productivity $\left(36.0 \mathrm{Mg} \mathrm{ha}^{-1}\right.$ ) (Cavalheiro et al., 2015). These values were lower than those found in the present study for NL (23.9), $\mathrm{PH}(17.4 \mathrm{~cm}), \mathrm{SD}(1.6$ $\mathrm{cm})$, SFM (182.4 g/plant), and SDM (11.0 g/plant), except productivity (29.5 $\mathrm{Mg} \mathrm{ha}^{-1}$ ) (Tab. 2).

However, the greater organic fertilizer doses, which resulted in the greatest SFM, SDM and productivity, were 213 (142\%), 274.5 (183\%) and $216(144 \%) \mathrm{kg}$ ha $^{-1}$ of $\mathrm{N}$, respectively; however, the technical and economic feasibility of such application must be evaluated for each situation (Tab. 2).

The evaluation of the mineral fertilization, ChM, CaM, earthworm humus and organic compost in the production of lettuce (Vera cultivar) indicated a higher production when using ChM (Abreu et al., 2010), presenting a SFM and SDM of 542.3 g, significantly higher when compared to the $91.1 \mathrm{~g}$ obtained with 
Table 2. Regressions of the effects of fertilizer doses on the plant variables.

\begin{tabular}{|c|c|c|c|c|c|}
\hline \multirow{2}{*}{ Variable } & \multirow{2}{*}{ Equation } & \multirow{2}{*}{$R^{2}$} & \multirow{2}{*}{ Value reached } & \multicolumn{2}{|c|}{$N$ doses } \\
\hline & & & & $\mathrm{kg} \mathrm{ha}^{-1}$ & $\%$ \\
\hline $\mathrm{NL}$ & $y=-0.0003 x^{2}+0.0919 x+16.853^{* *}$ & 0.92 & 23.9 & 229.5 & 153 \\
\hline $\mathrm{PH}$ & $y=-0.0003 x^{2}+0.0724 x+13.045^{* *}$ & 0.96 & $17.4(\mathrm{~cm})$ & 181.5 & 121 \\
\hline SD & $y=-3 E-05 x^{2}+0.0078 x+1.0583^{* *}$ & 0.94 & $1.6(\mathrm{~cm})$ & 195.0 & 130 \\
\hline SFM & $y=-0.0057 x^{2}+1.616 x+67.865^{* *}$ & 0.98 & 182.4 (g/plant) & 213.0 & 142 \\
\hline SDM & $y=-0.0002 x^{2}+0.0733 x+4.2798^{*}$ & 0.92 & 11.0 (g/plant) & 274.5 & 183 \\
\hline Yield & $y=-0.0009 x^{2}+0.259 x+10.822 * *$ & 0.98 & $29.5\left(\mathrm{Mg} \mathrm{ha}^{-1}\right)$ & 216.0 & 144 \\
\hline
\end{tabular}

${ }^{*}=$ significant at $1 \%$ and ${ }^{* *}=$ significant at $5 \%$, by the Tukey test $(P<0.05) . \mathrm{NL}=$ number of leaves; $\mathrm{PH}=$ plant height; $\mathrm{SD}=$ stem diameter; $\mathrm{SFM}=$ shoot fresh mass; SDM = shoot dry mass.

CaM and the $233.1 \mathrm{~g}$ obtained with mineral fertilization. Peixoto Filho et al. (2013) assessed the productivity of green-leaf lettuce (Cacheada cultivar) with doses of chicken, cattle and ovine manure in successive cultivations and observed that the ChM provided the best indices for the evaluated parameters: NL (15), SFM (141.4 g), SDM (5.5 g) and P (26.7 $\left.\mathrm{Mg} \mathrm{ha}^{-1}\right)$.

For the residual effect on soil chemical attributes for the type of fertilizer used, the CaM showed the highest levels of magnesium $(\mathrm{Mg})\left(1.7 \mathrm{cmol}_{\mathrm{c}} \mathrm{dm}^{-3}\right)$ and organic matter $\left(21 \mathrm{~g} \mathrm{~kg}^{-1}\right)$. Significant interactions between the fertilizers and doses for soil water $\mathrm{pH}, \mathrm{P}$ and $\mathrm{K}$ were detected (Tab. 3; Fig. 3). In general, it was observed that the ChM resulted in a linear increase in soil $\mathrm{pH}, \mathrm{P}$ and $\mathrm{K}$, which ranged from 6.5 to 6.8 , 19.9 to $86.8 \mathrm{mg} \mathrm{dm}^{-3}$ and from 0.2 to $0.5 \mathrm{cmol}_{\mathrm{c}} \mathrm{dm}^{-3}$, respectively; 5, 335 and $104 \%$ higher than the control (no fertilizer). The urea fertilizer linearly increased the content of $\mathrm{K}$ by $64 \%$, which ranged from 0.4 to $0.6 \mathrm{cmol}_{\mathrm{c}} \mathrm{dm}^{-3}$ and linearly decreased the $\mathrm{pH}$ value by $7 \%$, which ranged from 6.6 to 6.2 .

Table 3. Chemical attributes of $0 x i s o l$ cultivated with green-leaf lettuce under different fertilizers and doses.

\begin{tabular}{|c|c|c|c|c|c|c|c|}
\hline \multirow{4}{*}{ Fertilizer } & \multicolumn{7}{|c|}{ Soil chemical attributes } \\
\hline & $\mathrm{pH}$ & $\mathrm{P}$ & $\mathrm{K}$ & Ca & $\mathrm{Mg}$ & $\mathrm{H}+\mathrm{Al}$ & \multirow{2}{*}{$\frac{\mathrm{OM}}{\mathrm{g} \mathrm{kg}^{-1}}$} \\
\hline & $\mathrm{CaCl}_{2}$ & $\mathrm{mg} \mathrm{dm}^{-3}$ & \multicolumn{4}{|c|}{$\mathrm{cmol}_{\mathrm{c}} \mathrm{dm}^{-3}$} & \\
\hline & \multicolumn{7}{|c|}{ Fertilizers $(F)$} \\
\hline Urea & $6.4 b$ & $24.1 \mathrm{c}$ & $0.5 \mathrm{a}$ & 2.6 & $1.3 \mathrm{~b}$ & 1.9 & $18 b$ \\
\hline ChM & $6.7 \mathrm{a}$ & $49.2 \mathrm{a}$ & $0.3 \mathrm{~b}$ & 2.9 & $1.5 \mathrm{ab}$ & 1.7 & $19 b$ \\
\hline CaM & $6.6 \mathrm{a}$ & $37.9 \mathrm{~b}$ & $0.3 \mathrm{~b}$ & 2.8 & $1.7 \mathrm{a}$ & 1.9 & $21 \mathrm{a}$ \\
\hline \multirow[t]{2}{*}{ F-test } & $3.51^{*}$ & $16.10^{* *}$ & $35.98^{* *}$ & $2.20^{\mathrm{ns}}$ & $5.46^{* *}$ & $3.76^{\text {ns }}$ & $8.37^{* *}$ \\
\hline & \multicolumn{7}{|c|}{ Doses (D) } \\
\hline 0 & 6.6 & $19.6 \mathrm{~d}$ & $0.3 \mathrm{c}$ & 2.4 & 1.3 & 2.0 & 18 \\
\hline 25 & 6.5 & $28.2 \mathrm{~cd}$ & $0.4 \mathrm{~b}$ & 2.7 & 1.5 & 1.8 & 20 \\
\hline 50 & 6.7 & $33.1 \mathrm{c}$ & $0.3 \mathrm{c}$ & 2.7 & 1.5 & 1.8 & 19 \\
\hline 100 & 6.5 & $40.3 b$ & $0.4 \mathrm{~b}$ & 2.9 & 1.5 & 1.9 & 20 \\
\hline 150 & 6.6 & $52.0 \mathrm{a}$ & $0.4 \mathrm{~b}$ & 3.0 & 1.5 & 1.9 & 20 \\
\hline 200 & 6.5 & $49.1 \mathrm{a}$ & $0.5 \mathrm{a}$ & 3.0 & 1.6 & 1.8 & 19 \\
\hline \multirow[t]{2}{*}{ F-test } & $0.62^{\text {ns }}$ & $7.92^{* *}$ & $8.73^{* *}$ & $1.92^{\text {ns }}$ & $0.81^{\mathrm{ns}}$ & $1.25^{\text {ns }}$ & $1.84^{\text {ns }}$ \\
\hline & \multicolumn{7}{|c|}{ Interaction F x D } \\
\hline F-test & $2.33^{*}$ & $4.21^{* *}$ & $4.87^{* *}$ & $1.34^{\mathrm{ns}}$ & $0.91^{\mathrm{ns}}$ & $1.88^{\mathrm{ns}}$ & $1.37^{\mathrm{ns}}$ \\
\hline CV (\%) & 4.35 & 41.46 & 20.80 & 20.84 & 22.87 & 15.25 & 10.28 \\
\hline
\end{tabular}

${ }^{n s}=$ non significant $;{ }^{*}=$ significant at $1 \%$ and ${ }^{* *}=$ significant at $5 \%$, by the Tukey test $(P<0.05)$. ChM $=$ chicken manure; CaM $=$ cattle manure. 


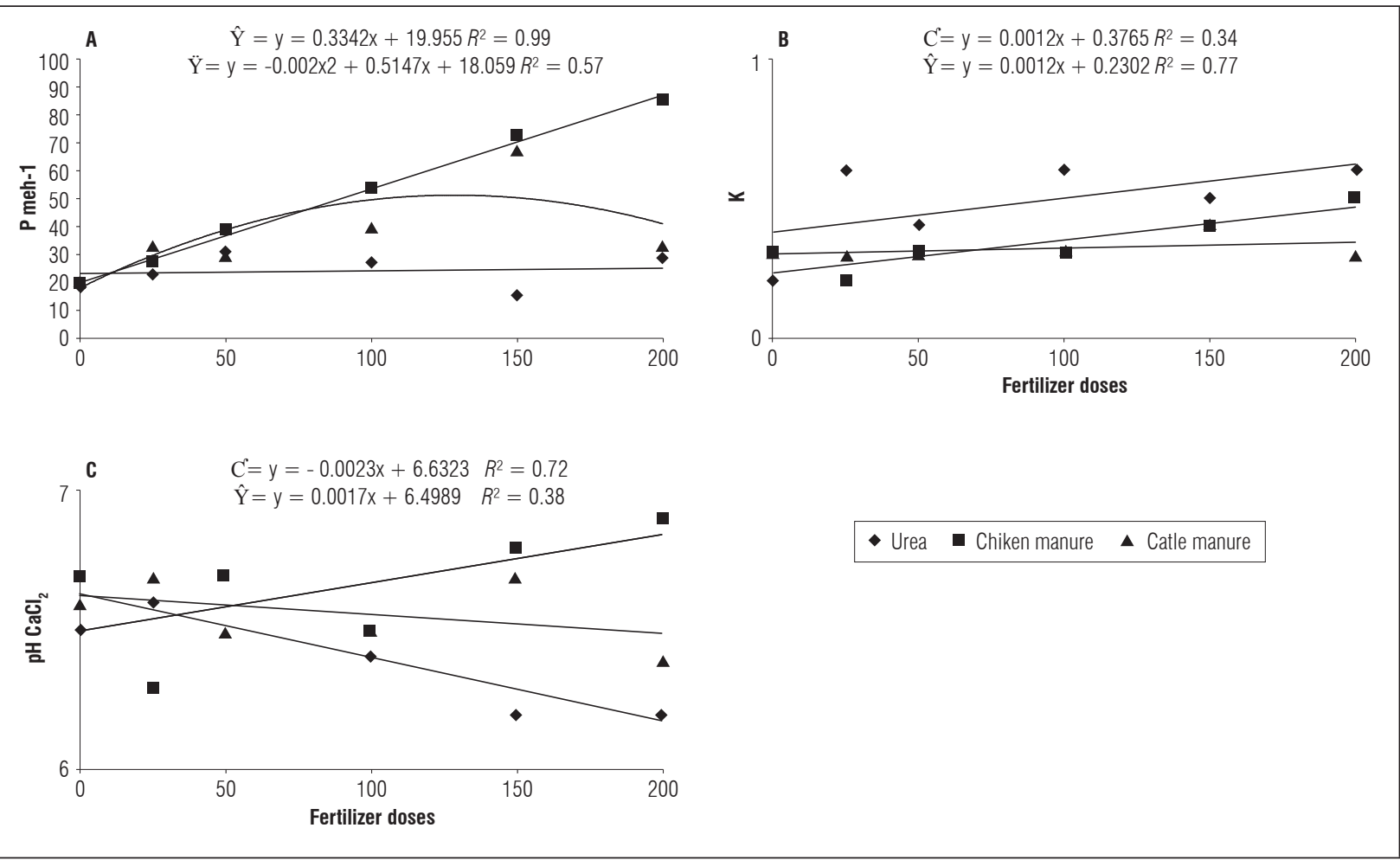

Figure 3. Regressions of the effect of doses of urea, chicken and cattle manure fertilizers on soil chemical attributes.

The increase in $\mathrm{P}$ availability, verified with the fertilization with ChM and CaM, was due to the presence of this nutrient in the manure composition, to the soil $\mathrm{pH}$ and to the rise in the soil organic matter content. The soil $\mathrm{pH}$ near neutrality provided conditions for $\mathrm{P}$ availability; in acidic conditions, there is a reaction of $\mathrm{H}_{2} \mathrm{PO}_{4}^{-}$with the ionic forms of iron $(\mathrm{Fe})$ and aluminum (Al), forming compounds with low solubility; also, the presence of organic matter blocks the adsorption sites on $\mathrm{Fe}$ and $\mathrm{Al}$ oxides in the soil, decreasing the adsorption capacity of $\mathrm{H}_{2} \mathrm{PO}_{4}^{-}$(Novais and Smyth, 1999).
The study of polynomial regression indicated that the soil $\mathrm{pH}$ in the soil fertilized with ChM and urea presented a linear adjustment, reaching values of 6.8 and 6.2 , respectively, with the $200 \%$ dose. The soil $\mathrm{P}$ when fertilized with $\mathrm{ChM}$ and $\mathrm{CaM}$ presented a linear and quadratic adjustment, respectively, reaching values of $86.8 \mathrm{mg} \mathrm{dm}^{-3}$ with the $200 \%$ dose and $51.2 \mathrm{mg} \mathrm{dm}^{-3}$ with the $129 \%$ dose. The soil $\mathrm{K}$ in the areas fertilized with urea and ChM presented a linear adjustment, reaching values of 0.6 and 0.5 cmolc dm ${ }^{-3}$ with the $200 \%$ fertilized doses, respectively (Tab. 4).

Table 4. Regression equations of the effect of doses of fertilizers on soil chemical attributes.

\begin{tabular}{|c|c|c|c|c|c|c|}
\hline Soil attribute & Equation & $R^{2}$ & Fertilizer & Value reached & Dose & Variation \\
\hline \multirow{2}{*}{ pH } & $y=-0.0023 x+6.6323^{* *}$ & 0.72 & Urea & 6.2 & 200 & -7 \\
\hline & $y=0.0017 x+6.4989^{*}$ & 0.38 & ChM & 6.8 & 200 & 5 \\
\hline \multirow{2}{*}{$\begin{array}{l}P \\
\left(m g d m^{-3}\right)\end{array}$} & $y=0.3342 x+19.955^{* *}$ & 0.99 & ChM & 86.8 & 200 & 335 \\
\hline & $y=-0.002 x^{2}+0.5147 x+18.059 *$ & 0.57 & CaM & 51.2 & 129 & 183 \\
\hline \multirow{2}{*}{$\begin{array}{l}\mathrm{K} \\
\left(\mathrm{mg} \mathrm{dm}{ }^{-3}\right)\end{array}$} & $y=0.0012 x+0.3765^{* *}$ & 0.34 & UR & 0.6 & 200 & 64 \\
\hline & $y=0.0012 x+0.2302^{* *}$ & 0.77 & ChM & 0.5 & 200 & 104 \\
\hline
\end{tabular}

${ }^{*}=$ significant at $1 \%$. and ${ }^{* *}=$ significant at $5 \%$, by the Tukey test $(P<0.05)$. ChM $=$ chicken manure; $\mathrm{CaM}=$ cattle manure; $\mathrm{pH}=$ soil water $\mathrm{pH} ; \mathrm{P}=$ phos phorus (Mehlich-1); $\mathrm{K}=$ potassium. 
Pimentel et al. (2009) conducted two experiments on lettuce and carrot [the first experiment was fertilized with organic compound ( $70 \%$ of Napier grass, $10 \%$ of remnants of cultures, $20 \%$ of cattle manure) at $0,4.2$, 8.4 and $16.8 \mathrm{~kg} /$ parcel (dry basis); the second experiment was fertilized with $1 / 3$ of the previous organic compound plus various grasses at $0,3.4,6.9$ and 13.7 $\mathrm{kg} \mathrm{parcel}^{-1}$ (dry basis)], and observed that the levels of $\mathrm{P}$ and $\mathrm{K}$ increased regardless of the organic compound used. The authors reported that the soil $\mathrm{pH}$ in both experiments was close to neutrality (6.7 and 6.6), as well as in the present study.

According to Mantovani et al. (2005), green-leaf lettuce (cultivar Verônica) fertilized with 0, 30, 60, 90 and $120 \mathrm{Mg} \mathrm{ha}^{-1}$ of urban waste compost presented linear increases in soil $\mathrm{pH}\left(\mathrm{CaCl}_{2}\right)$, soil organic matter, $\mathrm{P}, \mathrm{K}, \mathrm{Ca}$ and $\mathrm{Mg}$, with increases of $19,28,81$, 27,178 and $100 \%$, respectively, as compared to the control treatment (highest dose of organic fertilizer). This authors also reported that this effect on soil $\mathrm{pH}$ can be attributed to the presence of soluble organic anions (R-COO- and R-O-) in organic waste, which can adsorb $\mathrm{H}^{+}$from the soil solution with exchange reactions, especially with $\mathrm{Ca}^{2+}$ ions.
The correlation of the soil chemical characteristics and biomass production of the lettuce fertilized with organic compounds indicated that the addition of organic compounds increased the production of lettuce dry mass and the content of soil organic matter in the soil (Oliveira et al., 2014). These authors also reported that the rise of soil organic matter provided greater $\mathrm{P}, \mathrm{K}$ and Ca availability, in addition to a reduced soil potential acidity, favoring plant development and increasing productivity, similar to what was observed in the present study.

After harvest, there was still a residual of $49.2 \mathrm{mg}$ $\mathrm{dm}^{-3}$ of P in the plots fertilized with ChM (Tab. 5), indicating that there was a greater availability of this nutrient in an Oxisol (high P adsorption), which is a common soil in the Cerrado.

The microbiological quality and productivity of lettuce (Vera cultivar) under mineral and diverse organic fertilization treatments (control without fertilization, chemical fertilization, chicken manure, cattle manure, earthworm humus, organic compost) indicated that the fertilization with chicken manure provided the highest soil $\mathrm{pH}(7.1), \mathrm{K}\left(0.46 \mathrm{cmol}_{c} \mathrm{dm}^{-3}\right)$,

Table 5. Soil pH, phosphorus and potassium levels according to fertilizer.

\begin{tabular}{|c|c|c|c|c|c|c|c|}
\hline \multirow{3}{*}{ Fertilizer } & \multicolumn{6}{|c|}{ Doses } & \multirow{3}{*}{ Average } \\
\hline & 0 & 25 & 50 & 100 & 150 & 200 & \\
\hline & \multicolumn{6}{|c|}{$\mathrm{pH}$} & \\
\hline Urea & $6.5 \mathrm{aA}$ & $6.6 \mathrm{aA}$ & $6.7 \mathrm{aA}$ & $6.4 \mathrm{aA}$ & $6.2 \mathrm{bA}$ & $6.2 \mathrm{bA}$ & $6.4 \mathrm{~b}$ \\
\hline ChM & $6.7 \mathrm{aAB}$ & $6.3 \mathrm{aB}$ & $6.7 \mathrm{aAB}$ & $6.5 \mathrm{aAB}$ & $6.8 \mathrm{aAB}$ & $6.9 \mathrm{aA}$ & $6.7 \mathrm{a}$ \\
\hline CaM & $6.6 \mathrm{aA}$ & $6.7 \mathrm{aA}$ & $6.5 \mathrm{aA}$ & $6.5 \mathrm{aA}$ & $6.7 \mathrm{abA}$ & $6.4 \mathrm{abA}$ & $6.6 \mathrm{ab}$ \\
\hline Average & $6.6 \mathrm{~A}$ & $6.5 \mathrm{~A}$ & $6.7 \mathrm{~A}$ & $6.5 \mathrm{~A}$ & $6.6 \mathrm{~A}$ & $6.5 \mathrm{~A}$ & -- \\
\hline \multirow[t]{2}{*}{ CV (\%) } & \multicolumn{7}{|c|}{4.35} \\
\hline & \multicolumn{6}{|c|}{$\mathrm{P}\left(\mathrm{mg} \mathrm{dm}^{-3}\right)$} & \\
\hline Urea & $19.2 \mathrm{aA}$ & $23.8 \mathrm{aA}$ & $30.3 \mathrm{aA}$ & $26.5 \mathrm{bA}$ & $15.3 \mathrm{bA}$ & $29.3 \mathrm{bA}$ & $24.1 \mathrm{c}$ \\
\hline $\mathrm{ChM}$ & $18.5 \mathrm{aC}$ & $27.3 \mathrm{aBC}$ & $38.7 \mathrm{aBC}$ & 53.9 aAB & $72.3 \mathrm{aA}$ & $84.5 \mathrm{aA}$ & $49.2 \mathrm{a}$ \\
\hline CaM & $20.9 \mathrm{aB}$ & $33.6 \mathrm{aB}$ & $30.4 \mathrm{aB}$ & $40.5 \mathrm{abAB}$ & $68.4 \mathrm{aA}$ & $33.5 \mathrm{bB}$ & $37.9 b$ \\
\hline Average & 19.6 D & 28.2 CD & 33.1 BCD & $40.3 \mathrm{ABC}$ & $52.0 \mathrm{~A}$ & 49.1 AB & -- \\
\hline \multirow[t]{2}{*}{ CV $(\%)$} & \multicolumn{7}{|c|}{41.46} \\
\hline & \multicolumn{6}{|c|}{$\mathrm{K}\left(\mathrm{cmolc} \mathrm{dm}^{-3}\right)$} & \\
\hline Urea & $0.2 \mathrm{aC}$ & $0.6 \mathrm{aA}$ & $0.4 \mathrm{aB}$ & $0.6 \mathrm{aAB}$ & $0.5 \mathrm{aAB}$ & $0.6 \mathrm{aA}$ & $0.5 \mathrm{a}$ \\
\hline ChM & $0.3 \mathrm{aBC}$ & $0.2 \mathrm{bC}$ & $0.3 \mathrm{aBC}$ & $0.3 \mathrm{bABC}$ & $0.4 \mathrm{aAB}$ & $0.5 \mathrm{bA}$ & $0.3 \mathrm{~b}$ \\
\hline CaM & $0.3 \mathrm{aA}$ & $0.3 \mathrm{bA}$ & $0.3 \mathrm{aA}$ & $0.3 \mathrm{bA}$ & $0.4 \mathrm{aA}$ & $0.3 \mathrm{cA}$ & $0.3 \mathrm{~b}$ \\
\hline Average & $0.3 c$ & $0.4 \mathrm{abc}$ & $0.3 \mathrm{bc}$ & $0.4 a b$ & $0.4 \mathrm{a}$ & $0.5 \mathrm{a}$ & -- \\
\hline CV (\%) & \multicolumn{7}{|c|}{20.80} \\
\hline
\end{tabular}

Means followed by different letter indicate significant differences according to Tukey test $(P \leq 0.05)$. ChM $=$ chiken manure; CaM $=$ cattle manure. 
$\mathrm{Ca}\left(6.8 \mathrm{cmol}_{\mathrm{c}} \mathrm{dm}^{-3}\right), \mathrm{Mg}\left(1.1 \mathrm{cmol}_{\mathrm{c}} \mathrm{dm}^{-3}\right)$, and CTC $\left(11.2 \mathrm{cmol}_{\mathrm{c}} \mathrm{dm}^{-3}\right)$, while the fertilization with cattle manure showed the highest values for soil organic matter $\left(51.8 \mathrm{~g} \mathrm{~kg}^{-1}\right)$ and $\mathrm{P}\left(16 \mathrm{mg} \mathrm{dm}^{-3}\right)$, results that corroborate an improvement in soil chemical attributes when cultivated with organic fertilizers.

Mantovani et al. (2014) found that high doses of $\mathrm{P}$ resulted in an increased growth and production of green-leaf lettuce and observed that a dose of $350 \mathrm{mg}$ $\mathrm{dm}^{-3}$, equivalent to $800 \mathrm{~kg} \mathrm{ha}^{-1}$ of $\mathrm{P}_{2} \mathrm{O}_{5}$, was the most appropriate dose for clay soils (420 $\mathrm{g} \mathrm{kg}^{-1}$ of clay). Abreu et al. (2010) demonstrated that plants from treatments with organic composts showed a high foliar $\mathrm{P}$ and $\mathrm{K}$ content, higher than those observed in a mineral fertilization treatment. The authors also pointed out that $\mathrm{N}$ and $\mathrm{P}$ are the elements that most commonly limit lettuce production as a result of low availability in the soil.

\section{CONCLUSIONS}

The fertilization with cattle manure and chicken manure was more efficient than the mineral fertilization for the production of green-leaf lettuce, mainly because of $\mathrm{P}$ residual effects in the soil.

The chicken manure provided a higher soil $\mathrm{pH}$, phosphorus and potassium, and the cattle manure provided a higher magnesium, organic carbon and organic matter content.

The 144\% dose of organic fertilization (wet basis), corresponding to $72 \mathrm{Mg} \mathrm{ha}^{-1}$ of cattle manure and 29 $\mathrm{Mg} \mathrm{ha}^{-1}$ of chicken manure, resulted in the highest yield for green-leaf lettuce.

\section{ACKNOWLEDGMENT}

The authors thank the Federal Institute of Triângulo Mineiro, Campus Uberaba, for the infrastructure provided; the Foundation for Research Support of the State of Minas Gerais (FAPEMIG), the Brazilian National Council for Scientific and Technological Development (CNPq) for granting scholarships to the students, and the Agrisus Foundation for financing part of the project.

Conflict of interests: The manuscript was prepared and reviewed with the participation of the authors, who declare that there exists no conflict of interest that puts at risk the validity of the presented results.

\section{BIBLIOGRAPHIC REFERENCES}

Abreu, I.M.O., A.M.R. Junqueira, J.R. Peixoto, and S.A. Oliveira. 2010. Qualidade microbiológica e produtividade de alface sob adubação química e orgânica. Ciênc. Tecnol. Aliment. 30(Suppl. 1), 108-118. Doi: 10.1590/ S0101-20612010000500018

Beck, H.E., N.E. Zimmermann, T.R. Mcvicar, N. Vergopolan, A. Berg, and E.F. Wood. 2018. Present and future Köppen-Geiger climate classification maps at 1-km resolution. Sci. Data 5, 180214. Doi: 10.1038/ sdata.2018.214

Carvalho, N.L. and V. Zabot. 2012. Nitrogênio: nutriente ou poluente? Rev. Eletrônica Gest., Educ. Tecnol. Ambient. 6(6), 960-974. Doi: 10.5902/223611704671

Cavalheiro, D.B., E.S. Klosowski, N.P. Henkemeier, A.C. Gonçalves Junior, E.S. Vasconcelos, and E. Chibiaqui. 2015. Produção de alface (Lactuca sativa L.) cv. Vanda, cultivada sob diferentes ambientes e níveis de adubação mineral e orgânica. Cult. Saber 8(1), 109-124.

Cunha, E.Q., L.F. Stone, E.P.B. Ferreira, A.D. Didonet e J.A.A. Moreira. 2012. Atributos físicos, químicos e biológicos de solo sob produção orgânica impactados por sistemas de cultivo. Rev. Bras. Eng. Agríc. Ambient. 16(1), 56-63. Doi: 10.1590/S1415-43662012000100008.

Figueiredo, C.C., M.L.G. Ramos, C.M. McManus, and A.M. Menezes. 2012. Mineralização de esterco de ovinos e sua influência na produção de alface. Hortic. Bras. 30(1), 175-179. Doi: 10.1590/S0102-05362012000100029

Filgueira, F.A.R. 2013. Novo manual de olericultura: agrotecnologia moderna na produção e comercialização de hortaliças. $3^{\text {th }}$ ed. UFV, Viçosa, Brazil.

Inmet, Instituto Nacional de Meteorologia Brazil. 2018. Gráficos climatológicos. In: http://www.inmet.gov. br/portal/index.phpr=tempo/gráficos; consulted: August, 2019.

Mantovani, J.R., M.E. Ferreira, M.C.P. Cruz, and J.C. Barbosa. 2005. Alterações nos atributos de fertilidade em solo adubado com composto de lixo urbano. Rev. Bras. Ciênc. Solo 29(5), 817-824. Doi: 10.1590/ S0100-06832005000500017

Mantovani, J.R., I.A.C. Oliveira, D.J. Marques, A.B. Silva, and P.R.C. Landgraf. 2014. Teores de fósforo no solo e produção de alface crespa em função de adubação fosfatada. Semina: Ciênc. Agrár. 35(Suppl 4), 2369-2380. Doi: 10.5433/1679-0359.2014v35n4Suplp2369

Melo, L.C.A., C.A. Silva, and B.O. Dias. 2008. Caracterização da matriz orgânica de resíduos de origens diversificadas. Rev. Bras. Ciênc. Solo 32(1), 101-110. Doi: 10.1590/S0100-06832008000100010

Mota, W.F., R.D. Pereira, G.S. Santos, and J.C.B. Vieira. 2012. Agronomic and economic viability of intercropping 
onion and lettuce. Hortic. Bras. 30(2), 349-354. Doi: 10.1590/S0102-05362012000200028

Novais, R.F. and T.J. Smyth. 1999. Fósforo em solo e planta em condições tropicais. UFV, Viçosa, Brazil.

Oliveira, L.B., A.M.A. Accioly, C.L.R. Santos, R.A. Flores, and F.S. Barbosa. 2014. Características químicas do solo e produção de biomassa de alface adubada com compostos orgânicos. Rev. Bras. Eng. Agríc. Ambient. 18(2), 157-164. Doi: 10.1590/S1415-43662014000200005

Peixoto Filho, J.U., M.B.G.S. Freire, F.J. Freire, M.F.A. Miranda, L.G.M. Pessoa, and K.M. Kamimura. 2013. Produtividade de alface com doses de esterco de frango, bovino e ovino em cultivos sucessivos. Rev. Bras. Eng. Agríc. Ambient. 17(4), 419-424. Doi: 10.1590/ S1415-43662013000400010

Pereira, D.C., A. Wilsen Neto, and L.H.P. Nóbrega. 2013. Adubação orgânica e algumas aplicações agrícolas. Varia Sci. Agrár. 3(2), 159-174.

Pimentel, M.S. H. De-Polli, and A.M.Q. Lana. 2009. Atributos químicos do solo utilizando composto orgânico em consórcio de alface-cenoura. Pesqui. Agropecu. Trop. 39(3), 225-232.

Queiroz, A.A., V.B. Cruvinel, and K.M.E. Figueiredo. 2017. Produção de alface americana em função da fertilização com organomineral. Encicl. Biosf. 14(25), 1053106. Doi: 10.18677/EnciBio_2017A84

Ribeiro, A.C., P.T.G. Guimarães, and V.H. Alvarez V. (eds.). 1999. Recomendações para o uso de corretivos e fertilizantes em Minas Gerais. $5^{\text {th }}$ ed. Comissão de Fertilidade do Solo do Estado de Minas Gerais, Viçosa, Brazil.
Sala, F.C. and C.P. Costa. 2012. Retrospectiva e tendência da alfacicultura brasileira. Hortic. Bras. 30(2), 187-194. Doi: 10.1590/S0102-05362012000200002

Santos, H.G., P.K.T. Jacomine, L.H.C. Anjos, V.A. Oliveira, J.F. Lumbreras, M.R. Coelho, J.A. Almeida, T.J.F. Cunha, and J.B. Oliveira. 2018. Sistema brasileiro de classificação de solos. $5^{\text {th }}$ ed. Embrapa, Brasilia, Brazil.

Silva, E.M.N.C.P., R.L.F. Ferreira, S.E. Araújo Neto, L.B. Tavella, and A.J.S. Solino. 2011. Qualidade de alface crespa cultivada em sistema orgânico, convencional e hidropônico. Hortic. Bras. 29(2), 242-245. Doi: 10.1590/S0102-05362011000200019

Souza, J.L. 2007. Cultivo orgânico de hortaliças: Sistema de produção. CPT, Viçosa, Brazil.

Tedesco, M.J., P.A. Selbach, C. Gianello, and F.A.O. Camargo. 2008. Resíduos orgânicos no solo e os impactos no ambiente. In: Santos, G.A., L.S. Silva, L.P Canellas, and F.O. Camargo (eds.). 2008. Fundamentos da matéria orgânica do solo: ecossistemas tropicais e subtropicais. $2^{\text {nd }}$ ed. Metrópole, Porto Alegre, Brazil.

Vaz, J.C., A.T. Tavares, F.M. Haesbaert, I.D.P. Reyes, P.H.L. Rosa, T.A. Ferreira, and I.R. Nascimento. 2019. Adubação NPK como promotor de crescimento em alface. Rev. Agri-Environ. Sci. 5, e019003. Doi: 10.36725/ agries.v5i0.1215

Vergel, O.M, J.J. Martínez., and S.L. Zafra. 2016. Cultivo de cebolla (Allium cepa L.) en la provincia de Ocaña: factores asociados a la productividad y el rendimiento, Rev. Colomb. Cienc. Hortic. 10(2), 333-344. Doi: 10.17584/ rcch.2016v10i2.5070 